\title{
MINILAPAROSCOPIC FUNDOPLICATION. Technical adaptations and initial experience
}

\author{
Daniellson DIMBARRE1, Paula Marcelo de LOUREIRO'1, Christiano CLAUS ${ }^{1}$, \\ Gustavo CARVALHO² ${ }^{2}$ Pedro TRAUCZYNSKI ${ }^{1}$ and Fabiano ELIAS ${ }^{3}$
}

\begin{abstract}
Context - Gastroesophageal reflux diasease (GERD) is a highly prevalent disease. Treatment is divided into lifestyle modifications, medical and surgical treatment. Surgical laparoscopy is the gold standard treatment. In the last decade, there were an extensive research on procedures, less aggressive than laparoscopy and with better esthetic results. Minilaparoscopy is "re-emerging" as a safe, effective and with excellent cosmetic results in selected patients treated for gastroesophageal reflux diasease. We present a serie of 27 patients treated for GERD by minilaparoscopic laparoscopy. Material - Between October 2009-July 2011 a total of 27 patients underwent fundoplication by minilaparoscopy. It is used one 10-mm trocar, a telescope of 30 degrees and four $3 \mathrm{~mm}$ trocars at regular positions. Regular surgical steps are done with no modifications. Cardiac tape, suture needles, and eventually extracting bag, gauze, are placed and taked out through the umbilical port. With these technical adjustments, we can perform the procedure safely and effectively, similarly to standard laparoscopic technique. Results - Of the 27 patients, 22 were female and 5 male. The average body mass index was $25.5 \mathrm{~kg} / \mathrm{m}^{2}$. Hiatal hernias were small $(<3 \mathrm{~cm})$ in 24 patients. Mean operative time was 60 minutes. In all cases the hiatoplasty was performed with simple or ' $x$ ' stiches of 2.0 Ethibond. There was no need for conversion to standard laparoscopy or open surgery. The length of hospital stay was less than or equal to 24 hours in all patients. In this series of patients there were no postoperative complications. We did not observe any complication of the surgical wound. There were no evidence of recurrence of symptoms or endoscopic changes. Conclusion - Hiatoplasty associated with fundoplication using minilaparoscopic instruments is safe, feasible and effective. If compared to other "new access", has a spectacular esthetic results. Can be done with only minor technical adjustments, for any experienced laparoscopic surgeon, and is perfectly adaptable to our financial reality.
\end{abstract}

HEADINGS - Fundoplication. Laparoscopy. Surgical procedures, minimally invasive.

\section{INTRODUCTION}

Gastroesophageal reflux disease (GERD) associated or not with hiatal hernia is a highly prevalent disease, being responsible for $75 \%$ of esophageal diseases. Its incidence generally ranges from $10 \%-40 \%$, depending on the severity of symptoms ${ }^{(7)}$. Gastroesophageal reflux is caused by the abnormal reflux of gastric contents backwards into the esophagus, resulting in symptoms and esophageal mucosal injury. Heartburn, regurgitation and dysphagia are considered typical symptoms. Cough, chest pain, hoarseness and wheezing are some of the atypical symptoms ${ }^{(2,7)}$.

Treatment of gastroesophageal reflux is divided into changes in lifestyle, medical and surgical treatment. Surgical treatments at our disposal today are conventional open procedures, laparoscopic and endoscopic procedures ${ }^{(7)}$. Among them, the surgical laparoscopy is the gold standard treatment, since the endoscopic procedures have not yet proved effectiveness in the long term ${ }^{(7)}$. Since 2004, after the first publication on NOTES ${ }^{(8,14)}$ less invasive techniques with better cosmetic results than the already established laparoscopy has emerged. In Brazil, Gustavo Carvalho ${ }^{(3,4,5)}$ shown very convincing results in respect to cosmesis using instruments 2 and $3 \mathrm{~mm}$, without the need for costly new equipment, or extensive learning curves of new methods such as laparoendoscopic single site surgery (LESS) or NOTES ${ }^{(6,11,12,13)}$.

Our objective in this study is to present some technical adaptations that allows us to perform fundoplication and hiatoplasty with minilaparoscopic instruments. We will show our initial experience with the method.

\footnotetext{
Declared conflict of interest of all authors: none.

Jacques Perissat Institute, Minimally Invasive Surgery Department, Positivo University, Curitiba, PR; ${ }^{2}$ Pernambuco Federal University Minimally Invasive Surgery; ${ }^{3}$ Santa Cruz Hospital Minimally Invasive Surgery.

Correspondence: Dr. Daniellson Dimbarre - Rua República Argentina, 210 - conjunto 1.006 - Água Verde - 80240-210 - Curitiba, PR, Brazil. E-mail: daniellsondimbarre@ hotmail.com
} 


\section{METHODS}

Between October 2009 - July 2011 a total of 27 patients were selected for hiatoplasty with fundoplication by minilaparoscopy based on symptoms, endoscopy, SEED and manometry. Indications included patients without significant improvement of GERD symptoms after 6 months of treatment, at least, and/or complicated esophagitis. Contraindications to minilaparoscopy included patients with BMI $>35 \mathrm{~kg} / \mathrm{m}^{2}$, extensive abdominal scarring, hepatic steatosis and prior history of diffuse peritonitis. All patients were informed in advance through the informed consent. There were no conflict of interests.

\section{Surgical technique}

We routinely used a 32 FR Fouchet. We prefer to use a $\mathrm{Y}$ vertical intra-umbilical incision for better cosmesis. The $12 \mathrm{~mm} \mathrm{Hg}$ pneumoperitoneum is established. It is used (1) $10 \mathrm{~mm}$ trocar, a telescope of 30 degrees, and (4) $3 \mathrm{~mm}$ trocars at regular positions.

The dissection of the gastrofrenical ligament, angle of Hiss, pars flaccida, diaphragmatic pillars, esophagus, identification of the vagus nerve and the retrogastric space proceed the same way as the usual technique.

During repair, the use of $3 \mathrm{~mm}$ instruments leads us to some technical pitfalls. Cardiac tape, suture needles, and eventually extracting bag, gauze, are placed through the umbilical port. Another technicality is that after accomplishing the hiatoplasty, we do not cut the suture, being kept in the same location for further withdrawal inside a bag extractor.

Fundoplication is performed with ligation of short gastric vessels electively, posteriorly, with the use of ligatures or electrocautery. In order to accomplish the gastrofundoplication, we use a suture longer than usual, so that we have only one set of needle suture. Suture and needles used are drawn into the bag extractor, which is takedout of the cavity through the trocar of $10 \mathrm{~mm}$.

With these technical adjustments, we can perform the procedure safely and effectively, similarly to standard laparoscopic technique, with cosmesis far superior than conventional laparoscopy.

\section{RESULTS}

Of the 27 patients, 22 were female and 5 male. The average BMI was $25.5 \mathrm{~kg} / \mathrm{m}^{2}$. Hiatal hernias were small $(<3 \mathrm{~cm})$ in 24 patients. The preoperative manometry was performed in 19 patients and SEED in 3 patients. Mean operative time was 60 minutes. In all cases the hiatoplasty was performed with simple or ' $\mathrm{x}$ ' stiches of 2.0 Ethibond. In the first 17 cases we used a portal of $5 \mathrm{~mm}$ in the left hypochondrium for placement and removal of needles with $2 \mathrm{~mm}$ instruments and use of conventional needle holder.

After the development of the $3 \mathrm{~mm}$ needle holder, we began to use $3 \mathrm{~mm}$ instruments in all ports beyond the $10 \mathrm{~mm}$ port. There were no intraoperative complications. In two patients we changed from a port of $3 \mathrm{~mm}$ for a $5 \mathrm{~mm}$ port.
In one case, because the $3 \mathrm{~mm}$ instrument from the left hand of the surgeon has broken and in another case was identified in the inspection of the cavity, a liver with severe steatosis and we have decided to replace the $3 \mathrm{~mm}$ instrument for a $5 \mathrm{~mm}$ retractor to avoid iatrogenic liver damage. There was no need for conversion to standard laparoscopy or open surgery.

The length of hospital stay was less than or equal to 24 hours in all patients. In this series of patients there were no postoperative complications. Six patients underwent endoscopy between the 3 and 6 months after surgery and

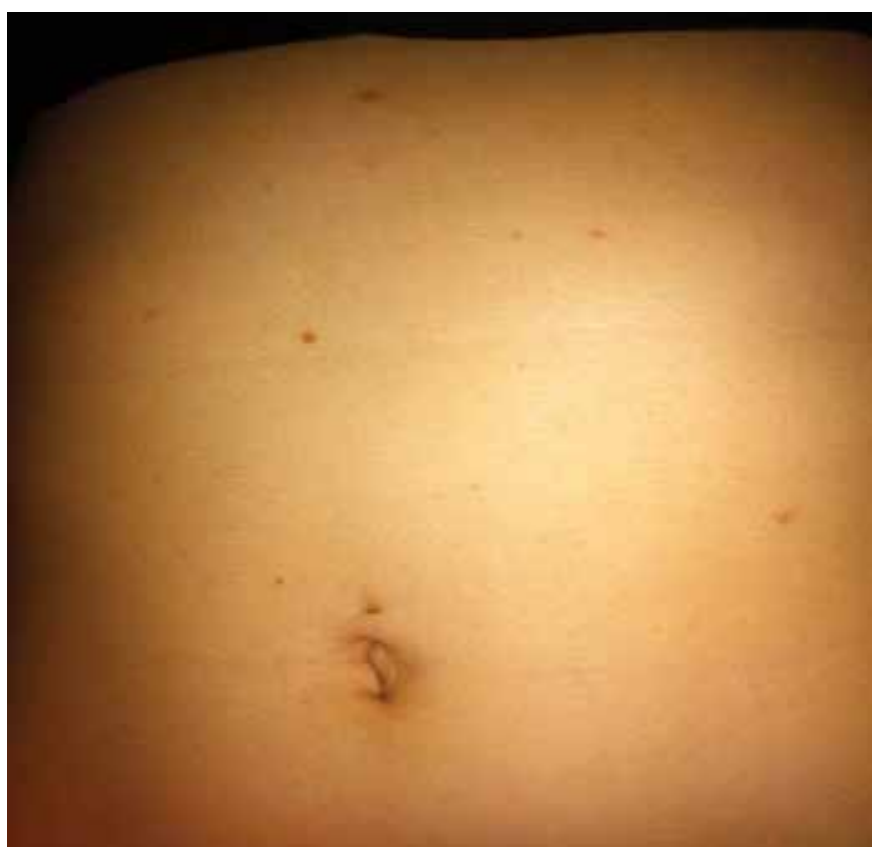

FIGURE 1. Aesthetic result

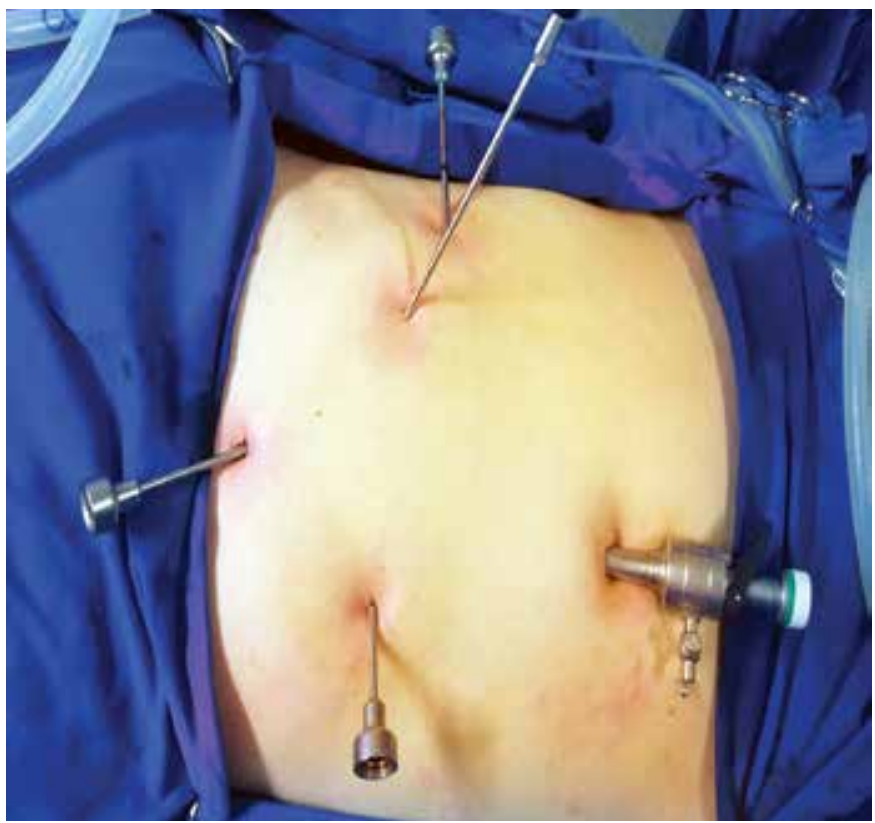

FIGURE 2. Trocars placement 
endoscopic fundoplication, and the rear view is exactly the same as conventional laparoscopic fundoplication.

We did not observe any complication of the surgical wound. There were no evidence of recurrence of symptoms or endoscopic changes.

\section{DISCUSSION}

GERD with or without hiatal hernia, occurs due to several mechanisms including incompetence of the LES or the mechanisms of antireflux barrier. Several studies demonstrate an important role in the hiatoplasty for the definitive correction of GERD ${ }^{(2,7)}$. Due to this fact, less aggressive endoscopic treatments than laparoscopic fundoplication has no wide acceptance in the surgical community worldwide. After the birth of NOTES, followed by LESS, there were a extensive research on procedures less aggressive than laparoscopy and with better aesthetic results ${ }^{(8,14)}$.

Based on the experience of several authors with minilaparoscopy and the development of new materials ${ }^{(1,3,6,9,10,11,12,13,14)}$, we have performed 27 gastrofundoplications using mini instruments. Of the 27 patients, 23 were female and 4 male. The average BMI was $25.5 \mathrm{~kg} / \mathrm{m}^{2}$. Hiatal hernias were small $(<3 \mathrm{~cm})$ in 21 patients. The preoperative manometry was performed in 20 patients and radiographs in 25 . Mean operative time was 60 minutes. There were no intraoperative complications. There was no need for conversion to standard laparoscopy or open surgery. The length of hospital stay was less than or equal to 24 hours in all patients. There were no postoperative complications. Six patients underwent endoscopy between the $3^{\text {rd }}$ and $6^{\text {th }}$ months after surgery, the rear view of the fundoplication is exactly the same as conventional laparoscopic fundoplication. There were no complications of the surgical wound and no recurrences.

Using the same steps as the already established laparoscopy, with small technical adjustments imported from laparoscopic cholecystectomy and inguinal hernioplasty, we performed hiatoplasty and fundoplication, with excellent cosmetic results in selected patients. With this technique, we do not add any disposable or expensive equipment other than a kit of $3 \mathrm{~mm}$ permanent instruments. This approach does not require any long learning curve, because the movements are the same as conventional laparoscopy.

If needed, we do not hesitate to enlarge the incision and change for a instrument of conventional laparoscopy. Thus, there is no additional risk to the method.

There are no long-term studies that demonstrate effectiveness of pure endoscopic techniques. However, nowadays, we are able to perform the fundoplication and hiatoplasty with the same principles already established, following the same technical steps, as safely and with excellent cosmetic results. No need to relearn a completely new technique in surgery as LESS, with its poor ergonomic conditions and with huge financial and time investments as NOTES techniques. Hiatoplasty associated with fundoplication using minilaparoscopic instruments is safe, feasible and effective. If compared to other "new access", has a spectacular esthetic results. Can be done with only minor technical adjustments, for any experienced laparoscopic surgeon, and is perfectly adaptable to our financial reality.

Dimbarre D, Loureiro PM, Claus C, Carvalho G, Trauczynski P, Elias F. Fundoplicatura por minilaparoscopia. Adaptações técnicas e experiência inicial. Arq Gastroenterol. 2012,49(3):223-6.

RESUMO - Contexto - A doença do refluxo gastroesofágico (DRGE) é uma doença altamente prevalente. O seu tratamento é dividido em modificações de estilo de vida, tratamento médico e cirúrgico. A cirurgia laparoscópica é o tratamento padrão-ouro. Nas últimas décadas houve uma extensa pesquisa sobre procedimentos menos agressivos do que a laparoscopia e com melhores resultados estéticos. A minilaparoscopia vem "reemergindo" como método seguro, eficaz e com excelentes resultados estéticos em pacientes selecionados, tratados para DRGE. É apresentada uma série de 27 pacientes tratados para a DRGE por minilaparoscopia. Métodos - Entre outubro de 2009 e julho de 2011, o total de 27 pacientes foi submetido a fundoplicatura por videominilaparoscopia. Foram utilizados um trocarte de $10 \mathrm{~mm}$, um telescópio de 30 graus e quatro trocarteres de $3 \mathrm{~mm}$ nas posições regulares. Os passos cirúrgicos são feitos sem modificações, de maneira habitual. Fita cardíaca, agulhas de sutura e, eventualmente, saco extrator e gaze são colocados e retirados através do portal umbilical. Com esses ajustes técnicos, pode-se realizar o procedimento de forma segura e eficaz, semelhantemente à técnica laparoscópica padrão. Conclusão - Hiatoplastia associada à fundoplicatura laparoscópica, utilizando-se de instrumentos minilaparoscópicos é método seguro, viável e eficaz. Se comparado a outros "novos acessos", tem resultado estético espetacular. Pode ser realizado com apenas pequenos ajustes técnicos, por qualquer cirurgião experiente em laparoscopia e é perfeitamente adaptável a nossa realidade financeira.

DESCRITORES - Fundoplicatura. Laparoscopia. Procedimentos cirúrgicos minimamente invasivos. 


\section{REFERENCES}

1. Blinman T. Incisions do not simply sum. Surg Endosc. 2010 [Epub ahead] doi:10.1007/s00464-009-0854-z.

2. Cappel, MS. Clinical presentation, diagnosis, and management of gastroesophageal reflux disease. Med Clin North Am. 2005;89:243-91.

3. Carvalho GL, Cavazzola LT. Can mathematic formulas help us with our patients. Surg Endosc. 2010 [Epub ahead of print]. doi: 10.1007/s00464-010-1065-3.

4. Carvalho GL, Silva FW, Ramos CHC. Colecistectomia minilaparoscópica sem utilização de endoclipes: técnica e resultados em 719 casos. Rev Bras Videocir. 2007;1:5-11.

5. Carvalho GL, Silva FW, Silva JS, de Albuquerque PP, Coelho R de M, Vilaça TG, Lacerda CM. Needlescopic clipless cholecystectomy as an efficient, safe, and cost-effective alternative with diminutive scars: the first 1,000 cases. Surg Laparosc Endosc Percutan Tech. 2009;19:368-72.

6. Cheah WK, Lenzi JE, So JB, Kum CK, Goh PM. Randomized trial of needlescopic versus laparoscopic cholecystectomy. Br J Surg. 2001;88:45-7.

7. DeVault, TD, Castell, BT. Guidelines for the diagnosis and treatment of gastroesophageal reflux disease. Updated guidelines for the diagnosis and treatment of gastroesophageal reflux disease. 2008.
8. Ko CW, Kalloo AN. Per-oral transgastric abdominal surgery. Chin J Dig Dis. 2006;7:67-70.

9. Mamazza J, Schlachta CM, Seshadri PA, Cadeddu MO, Poulin EC. Needlescopic surgery: A logical evolution from conventional laparoscopic surgery. Surg Endosc. 2001;15:1208-12.

10. Perissat J. Laparoscopic cholecystectomy: the European experience. Am J Surg 1993;165:444-9.

11. Reardon PR, Kamelgard JI, Applebaum B, Rossman L, Brunicardi FC. Feasibility of laparoscopic cholecystectomy with miniaturized instrumentation in 50 consecutive cases. World J Surg. 1999;23:128-31.

12. Sarli L, Costi R, Sansebastiano G, Mini-laparoscopic cholecystectomy vs laparoscopic cholecystectomy. Surg Endosc. 2001;15:614-8.

13. Schwenk W, Neudecker J, Mall J, Bohm B, Muller JM. Prospective randomized blinded trial of pulmonary function, pain, and cosmetic results after laparoscopic vs. microlaparoscopic cholecystectomy. Surg Endosc. 2000;14:345-8.

14. Zorron R, Maggioni LC, Pombo L, Oliveira AL, Carvalho GL, Filgueiras M NOTES transvaginal cholecystectomy: preliminary clinical application. Surg Endosc. 2008;22:542-7.

Received 9/11/2011 Accepted 5/6/2012. 